\title{
Comparative Effects of Physostigmine and Neostigmine on Acquisition and Performance of a Conditioned Avoidance Behavior in the Rat'
}

\author{
JOHN A. ROSECRANS ${ }^{2}$ AND EDWARD F. DOMINO \\ Michigan Neuropsychopharmacology Research Program, Department of Pharmacology, \\ University of Michigan, Ann Arbor, Michigan 48104
}

(Received 14 March 1973)

\begin{abstract}
ROSECRANS, J. A. AND E. F. DOMINO. Comparative effects of physostigmine and neostigmine on acquisition and performance of a conditioned avoidance behavior in the rat. PHARMAC. BIOCHEM. BEHAV. 2(1) 67-72, 1974. - The actions of physostigmine $(0.10$ and $0.15 \mathrm{mg} / \mathrm{kg})$ and neostigmine $(0.12 \mathrm{mg} / \mathrm{kg})$ given s.c. on acquisition and performance of conditioned pole jumping were studied in rats receiving either $0.9 \%$ saline, $(-)$ hyoscyamine or atropine methylnitrate. As estimated by inhibition of acetylcholinesterase (AChE) activity, physostigmine but not neostigmine entered the rat brain. Even though neostigmine did not significantly alter brain AChE activity in equimolar doses to physostigmine, it depressed both the acquisition and performance of a behavioral task, suggesting a predominant peripheral action. Although physostigmine depressed behavior mainly via a central action, its peripheral actions also play a role in its behavioral effects.
\end{abstract}

Physostigmine Neostigmine Conditioned avoidance Central and peripheral drug action

PHYSOSTIGMINE is a reversible cholinesterase inhibitor (ChEI) which has been useful in studying cholinergic mechanisms of behavior $[1,3,4,6-10]$. Its presence in the central nervous system can be determined indirectly by its effects on brain ChE. Because of its reversible nature, one can measure both the onset and recovery of its behavioral effects. There is a good correlation between inhibition of brain acetylcholinesterase activity (AChE), an increase in brain acetylcholine ( $\mathrm{ACh}$ ), and behavioral depression following physostigmine $[3,8]$.

While this approach appears valid in studying the behavioral role of brain $\mathrm{ACh}$, there are problems associated with the use of physostigmine and related compounds. Aside from its central effect, physostigmine has well known peripheral actions. In view of the fact that the blood-brain barrier tends to exclude quaternary nitrogen compounds, the tertiary and quaternary analogs of various cholinergic agonists and antagonists can be useful tools to determine relative central $v s$ peripheral effects. The additional measure of brain $\mathrm{AChE}$ activity provides further evidence that a ChEI has penetrated into the central nervous system.

The purpose of the present study was to determine the effects of the cholinesterase inhibitors physostigmine (a tertiary amine) and neostigmine (a quaternary amine) on acquisition and performance of conditioned pole jumping and correlate their behavioral effects with brain AChE activity in the rat. Two cholinergic antagonists were also used to separate their central and peripheral effects. One was (-) hyoscyamine, the active isomer of atropine (a tertiary amine) and the other methyl atropine (a quaternary amine). Although similar studies have been reported [3, 4 $7,8-10]$, the correlation of brain Ach $E$ activity with behavioral effects only rarely has been done.

\section{METHOD}

Male albino Holtzman rats from 45-90 days of age were used. Acquisition and performance studies were conducted utilizing the rat pole jump response as described previously [8]. Both initiation and recording of trials and responses was accomplished automatically. The CS was a $5 \mathrm{sec}$ buzzer which overlapped a 5 sec US consisting of a 1 ma shock scrambled through the grid floor. Intertrial periods ranged from $20-40 \mathrm{sec}$ with a mean of $30 \mathrm{sec}$. Responses during

'Supported in part by USPHS MH-11846.

${ }^{2}$ Present address: Department of Pharmacology, Medical College of Virginia, Richmond, Virginia. 
the intertrial period were not counted. Animals were allowed to habituate to the animal room for one week prior to testing, during which time they were numbered and placed in a predesigned group utilizing a random table. Experiments were conducted in blocks consisting of one control and five experimental groups of 12 animals each. Saline, (-) hyoscyamine or methyl atropine was administered $30 \mathrm{~min}$ prior to the administration of the ChEIs physostigmine and neostigmine. Drugs were administered s.c. Dosage was calculated as base.

\section{Acquisition Studies}

Prior to the initial avoidance sessions, naive animals were placed in the behavioral situation for a five min acclimitization period and administered the ChEI. Cholinergic antagonists were administered 25 min prior to placement in the experimental chamber. Thereafter, animals received 75 avoidance trials. The criterion for learning was nine consecutive avoidances out of 10 trials. All avoidance and escape data was expressed as percent of 75 trials.

\section{Performance Studies}

Animals were treated in this experiment as in the acquisition study except that they were further trained in two additional acquisition sessions prior to drug treatment. Prior to the fourth session, avoidance behavior ranged between $96 \pm 4 \%(n=12)$ and $98.2 \pm 3 \%(n=14)$. Trained animals received either methyl atropine or $(-)$ hyoscyamine in equimolar doses and were presented 50 trials. Following the 50 th trial ( $30 \mathrm{~min}$ later) animals were removed from the situation and administered either physostigmine or neostigmine in equimolar doses, and returned for an additional 100 trials. Drug effects were compared on the ability to depress avoidance behavior by at least $50 \%$. The duration of time was determined between the period of onset and recovery of $50 \%$ avoidance behavior.

\section{Brain Acetylcholinesterase Activity}

In a separate group of animals $\mathrm{AChE}$ activity was estimated at various times after drug administration. Following sacrifice of the animals by decapitation, the brains were quickly removed, weighed and homogenized in 9 volumes of cold saline $(0.9 \% \mathrm{NaCl})$. A one $\mathrm{ml}$ aliquot of brain homogenate was diluted to $1: 30$ with $0.9 \%$ saline and allowed to equilibrate to a temperature of $37.5^{\circ} \mathrm{C}$ in a water bath. During this period ( $10 \mathrm{~min}), \mathrm{pH}$ was adjusted to 7.4. An in vitro concentration of $\mathrm{ACh}\left(3 \times 10^{-3} \mathrm{M}\right.$ based on a $30 \mathrm{ml}$ bath) was added to the assay medium and its rate of hydrolysis was followed utilizing the $\mathrm{pH}$ Stat method described before [8]. The rate of ACh hydrolysis (minus blank) was equivalent to $\mu \mathrm{M}$ of $\mathrm{NaOH}$ titrated. AChE activity was expressed as the $\mu \mathrm{M}$ of $\mathrm{ACh}$ hydrolyzed/g/hr. The substrate in dose-response physostigmine experiments was methacholine. This substrate was utilized because, in our hands, $\mathrm{ACh}$ hydrolysis rates were curvilinear when $\mathrm{AChE}$ was inhibited more than $60 \%$ with reversible inhibitors. This was not so with methacholine as rates were linear regardless of inhibitor or assay environment.

\section{Brain A cetylcholine}

At appropriate time intervals, rats were sacrificed by decapitation, brain tissue removed, the cerebellum excised and the right half of the cerebrum frozen in isopentane contained in a beaker surrounded by ethanol and dry ice. Total AChE was determined in the left cerebrum as described above. Total ACh levels in the frozen samples of the right cerebrum were determined using the frog rectus abdominus assay as described previously [8].

\section{RESULTS}

Dose Response Relations of Physostigmine on Rat Brain Acetylcholinesterase and Acetylcholine

Our initial objective was to obtain further information concerning the effects of various doses of physostigmine on brain ACh and AChE in animals pretreated with $2.1 \mathrm{mg} / \mathrm{kg}$ of methyl atropine. The data presented in Table 1 indicate that all doses studied significantly increased brain $\mathrm{ACh}$ and reduced brain AChE activity. A linear dose response effect was observed in relation to AChE. The slope was much more steep with brain $\mathrm{ACh}$ and leveled off at doses above $0.25 \mathrm{mg} / \mathrm{kg}$ of physostigmine.

Maximal stimulation of the cholinergic system was evidenced at higher doses $(1.0 \mathrm{mg} / \mathrm{kg})$ as indicated by extreme muscular fasiculation, chromodacryorrhea (bloody tears), salivation and diarrhea. Animals receiving between 0.125 and $0.250 \mathrm{mg} / \mathrm{kg}$ of physostigmine were not overtly affected. This therefore, was a good dose range for studying the behavioral effects of this drug.

TABLE 1

EFFECTS OF PHYSOSTIGMINE ON BRAIN ACh AND AChE LEVELS IN RATS PRETREATED WITH METHYL ATROPINE

\begin{tabular}{lcc}
\hline $\begin{array}{c}\text { Dose } \\
(\mathrm{mg} / \mathrm{kg})\end{array}$ & $\begin{array}{c}\mathrm{AChE} \\
\mu \mathrm{mol} / \mathrm{g} / \mathrm{hr}\end{array}$ & $\begin{array}{c}\mathrm{ACh} \\
\mathrm{nmol} / \mathrm{g}\end{array}$ \\
\hline 0 & $320 \pm 7$ & $10.2 \pm 1.2$ \\
0.125 & $240 \pm 41$ & $15.2 \pm 1.0$ \\
& $(-22 \%)$ & $(+49 \%)$ \\
0.250 & $220 \pm 34$ & $24.4 \pm 3.9$ \\
& $(-31 \%)$ & $(+129 \%)$ \\
1.000 & $176 \pm 26$ & $26.2 \pm 2.5$ \\
& $(-47 \%)$ & $(+156 \%)$ \\
& $132 \pm 38$ & $29.4 \pm 4.0$ \\
& $(-59 \%)$ & $(+194 \%)$ \\
\hline
\end{tabular}

All values are means \pm S.E. of 6 animals at each dose of physostigmine. $\mathrm{ACh}$ and $\mathrm{AChE}$ were obtained from the same animals using one half of each brain for separate assays. Rats were pretreated with methyl atropine $(2.1 \mathrm{mg} / \mathrm{kg}$, s.c.) $30 \mathrm{~min}$ prior to physostigmine, and were sacrificed $20 \mathrm{~min}$ thereafter. The figures in ( ) indicate the change from control. Note that in these methyl atropine treated animals the decrease in AChE was paradoxically less than one would expect. In addition the control levels of brain $\mathrm{ACh}$ are also lower than usually reported. 
Effects of (-) Hyoscyamine and Methyl Atropine on Acquisition and Performance of Conditioned Pole-jumping

(-) Hyoscyamine in low doses $(0.30-0.50 \mathrm{mg} / \mathrm{kg})$ had little effect on acquisition. A biomodal effect was observed with larger amounts (Table 2). A dose of $0.75 \mathrm{mg} / \mathrm{kg}$, s.c. significantly facilitated behavior, while inhibition was observed at $1.0 \mathrm{mg} / \mathrm{kg}$. The drug had no effect on performance of conditioned avoidance responses in doses up to $8.0 \mathrm{mg} / \mathrm{kg}$. Equimolar doses of the quaternary anticholinergic drug, methyl atropine, had no effect on either acquisition or performance of this behavior.

Effects of Physostigmine and Neostigmine on Acquisition of Conditioned Pole-jumping

Physostigmine in doses of 0.10 and $0.15 \mathrm{mg} / \mathrm{kg}$ prevented rats from learning this task (Table 3 ). This was evident in all parameters used. The effects were dose related inasmuch as $0.15 \mathrm{mg} / \mathrm{kg}$ caused a reduction in \% avoidance and escape behavior almost twice that caused by $0.10 \mathrm{mg} / \mathrm{kg}$. After physostigmine $(0.10 \mathrm{mg} / \mathrm{kg}$, s.c. $)$ alone 73.7 trials were required for criterion while after methyl atropine plus physostigmine 67.0 trials were required. An equimolar dose of $(-)$ hyoscyamine produced a much greater antagonism of $0.10 \mathrm{mg} / \mathrm{kg}$ of physostigmine. Interestingly, the larger dose of $0.15 \mathrm{mg} / \mathrm{kg}$ of physostigmine was not as significantly antagonized by $(-)$ hyoscyamine. (-) Hyoscyamine $(1.0 \mathrm{mg} / \mathrm{kg})$ plus physostigmine $(0.15 \mathrm{mg} / \mathrm{kg})$ resulted in an even greater suppression of acquisition. Trials to criteria were increased to $62.9 \pm 4.7$, while $\%$ avoidance was decreased to $25.0 \pm 8.5$.
TABLE 2

EFFECTS OF VARIOUS DOSES OF (-) HYOSCYAMINE ON ACQUISITION OF POLE JUMPING

\begin{tabular}{llll}
\hline $\begin{array}{l}\text { Dose } \\
\mathrm{mg} / \mathrm{kg}\end{array}$ & $\begin{array}{c}\text { Trials to } \\
\text { Criterion }\end{array}$ & $\begin{array}{c}\text { Mean \% } \\
\text { Avoidance }\end{array}$ & $\begin{array}{c}\text { Mean \% } \\
\text { Escape }\end{array}$ \\
\hline 0 & $47.1 \pm 2.4$ & $57.2 \pm 3.0$ & $8.1 \pm 1.7$ \\
0.30 & $47.8 \pm 5.7$ & $58.5 \pm 5.5$ & $17.3 \pm 3.9$ \\
0.50 & $46.0 \pm 3.3$ & $57.9 \pm 4.9$ & $16.6 \pm 2.5$ \\
0.75 & $37.9 \pm 3.2 *$ & $69.1 \pm 4.1 *$ & $10.3 \pm 1.5$ \\
1.00 & $57.9 \pm 6.4 *$ & $38.0 \pm 8.9$ & $10.7 \pm 2.9$ \\
\hline
\end{tabular}

All values are means \pm S.E. of 12 animals per group.

*Significant from saline controls at $p<0.05$ (Mann-Whitney $\mathbf{U}$ Test).

TABLE 3

EFFECTS OF PHYSOSTIGMINE ON ACQUISITION TO THE POLE JUMP RESPONSE

\begin{tabular}{lcccc}
\hline $\begin{array}{l}\text { Drug } \\
\text { Pretreatment }\end{array}$ & $\begin{array}{c}\text { Dose of } \\
\text { Physostigmine }\end{array}$ & $\begin{array}{c}\text { Trials to } \\
\text { Criterion }\end{array}$ & $\begin{array}{c}\% \\
\text { Avoidance }\end{array}$ & $\begin{array}{c}\% \\
\text { Escape }\end{array}$ \\
\hline Saline & 0.0 & $47.5 \pm 3.2$ & $47.3 \pm 5.3$ & $12.8 \pm 2.3$ \\
Saline & 0.10 & $73.7 \pm 1.2^{*}$ & $12.9 \pm 4.8^{*}$ & $26.1 \pm 6.9$ \\
Saline & 0.15 & $>75^{*}$ & $3.1 \pm 1.5^{*}$ & $14.2 \pm 7.0$ \\
$\begin{array}{l}\text { Methyl atropine } \\
1 \mathrm{mg} / \mathrm{kg}\end{array}$ & 0.10 & $67.0 \pm 4.7$ & $22.2 \pm 9.4^{*}$ & $20.2 \pm 9.9$ \\
$\begin{array}{l}\text { Methyl atropine } \\
1 \mathrm{mg} / \mathrm{kg}\end{array}$ & 0.15 & $73.3 \pm 4.5^{*}$ & $6.0 \pm 3.0$ & $11.7 \pm 4.7$ \\
$\begin{array}{l}(-) \mathrm{Hy} \text { oscyamine } \\
0.5 \mathrm{mg} / \mathrm{kg}\end{array}$ & 0.10 & $55.4 \pm 5.0$ & $42.9 \pm 10.2 \dagger$ & $16.8 \pm 4.9$ \\
$\begin{array}{l}(-) \mathrm{Hy} \text { (1) } \\
0.5 \mathrm{mg} / \mathrm{kg}\end{array}$ & 0.15 & $60.6 \pm 4.1 *$ & $35.0 \pm 7.5^{*}$ & $13.4 \pm 3.1$ \\
\hline
\end{tabular}

All values represent the means \pm S.E. for 12 animals per group

*Significantly different from saline alone, $p<0.05$ (Mann-Whitney U Test).

$\dagger$ Significantly different from methyl atropine pretreated animals, $p<0.05$ (Mann-Whitney U Test)

Drug pretreatments were given 30 min before the physostigmine. 
The effects of neostigmine in a dose equimolar to $0.15 \mathrm{mg} / \mathrm{kg}$ physostigmine, on the other hand, could not be antagonized by any of the pretreatments (Table 4). Both cholinergic antagonists appeared to alter escape responding without affecting \% avoidance after neostigmine. However, regardless of pretreatment, none of the 36 rats given neostigmine were able to learn this task. While these animals were not able to reach criteria ( 9 out of 10 avoidance responses), total \% responding (\% escape $+\%$ avoidance) indicated that these rats had learned the task to some degree. In contrast, animals receiving equimolar doses of physostigmine $(0.150 \mathrm{mg} / \mathrm{kg})$ made one third less total responses than those given neostigmine.

TABLE 4

EFFECTS OF NEOSTIGMINE ON ACQUISITION OF THE POLE JUMP RESPONSE

\begin{tabular}{lccc}
$\begin{array}{l}\text { Drug } \\
\text { Pretreatment }\end{array}$ & $\begin{array}{c}\text { Trials to } \\
\text { Criterion }\end{array}$ & $\%$ & $\%$ \\
& Avoidance & Escape \\
\hline
\end{tabular}

$\begin{array}{llll}\begin{array}{l}\text { None }+ \text { saline } \\ \text { instead of } \\ \text { neostigmine }\end{array} & 50.0 \pm 3.3 & 55.3 \pm 3.2 & 17.4 \pm 1.6 \\ \text { Saline } & 74.0 \pm 0.9 & 14.5 \pm 3.0 & 35.4 \pm 6.8 \\ \begin{array}{l}\text { Methyl atropine } \\ 1 \mathrm{mg} / \mathrm{kg}\end{array} & 73.0 \pm 1.4 & 12.2 \pm 0.7 & 28.7 \pm 7.1 \\ \begin{array}{l}(-) \mathrm{Hyoscyamine} \\ 0.5 \mathrm{mg} / \mathrm{kg}\end{array} & 71.1 \pm 1.8 & 17.8 \pm 3.9 & 21.0 \pm 5.4 \\ \end{array}$

Each value represents the mean \pm S.E. of 12 animals per group. All values obtained with neostigmine were significantly different from saline control data at $p<0.001$ (Mann-Whitney U Test).

Pretreatments were given $30 \mathrm{~min}$ before neostigmine, 0.12 $\mathrm{mg} / \mathrm{kg}$.

Effects of Equimolar Doses of Physostigmine and Neostigmine on Conditioned Pole-jumping Performance and Correlations with Brain Acetylcholinesterase Activity

As indicated in Table 5, the duration of depression of performance on pole jump avoidance lasted $37.3 \mathrm{~min}$ following $0.15 \mathrm{mg} / \mathrm{kg}$ of physostigmine. This effect was reduced by $60 \%$ with methyl atropine and was completely antagonized with an equimolar dose of $(-)$ hyoscyamine. In contrast, the effects of neostigmine $(0.12 \mathrm{mg} / \mathrm{kg})$ could not be blocked by either cholinergic antagonist.

Neostigmine produced a severe behavioral depression with no effect on brain AChE activity. On the other hand, the behavioral effects following an equimolar dose of physostigmine correlated initially with a reduction of brain AChE activity but not during recovery as indicated in Fig. 1. The latter finding is quite surprising and suggests some adaptation to lowered brain AChE activity.

\section{TABLE 5}

EFFECTS OF NEQSTIGMINE AND PHYSOSTIGMINE ON AVOIDANCE PERFORMANCE IN TRAINED RATS

\begin{tabular}{ccc} 
& \multicolumn{2}{c}{ Duration of Behavioral Depression } \\
Neostigmine & Physostigmine \\
Pretreatment & $0.12 \mathrm{mg} / \mathrm{kg}$ & $0.15 \mathrm{mg} / \mathrm{kg}$
\end{tabular}

Saline

$25.4 \pm 2.5$

(6)

Methyl Atropine

$2.1 \mathrm{mg} / \mathrm{kg}$

$26.5 \pm 2.9$

(18)

(-) Hyoscyamine

$1.0 \mathrm{mg} / \mathrm{kg}$

$21.9 \pm 6.2$

(6)

$37.3 \pm 2.4$

(6)

$14.6 \pm 4.5 *$

$0.0 \dagger$

(6)
All values are means \pm S.E. ( $\mathrm{min}$ ) with the number of animals indicated in parentheses. The duration of behavioral depression was calculated from the onset of 50\% avoidance to recovery of $50 \%$ avoidance. \% avoidance was determined at $5 \mathrm{~min}$ intervals of each $6-7$ trials.

${ }^{*} p<0.05$

$\dagger p<0.001$

\section{DISCUSSION}

The basic new information of this study is that neostigmine can dramatically depress behavior in reasonable doses compared to physostigmine. This depression is not associated with any significant changes in brain AChE activity. Without measures of brain AChE activity and the use of selective tertiary and quaternary cholinergic antagonists, one might conclude that equimolar amounts of these two agonists act to suppress behavior by a similar mechanism. (-) Hyoscyamine is an effective antagonist of physostigmine in doses which do not affect neostigmine. Although neostigmine did not alter brain AChE activity, it did impair both acquisition and performance, presumable by its marked peripheral actions. In contrast, the behavioral suppressant effects of physostigmine are associated with a decrease in brain AChE activity and seem to be due primarily to its central actions as has been suggested by others.

These results also indicate that acquisition of avoidance behavior is a much more sensitive endpoint than performance. The depressant effects of physostigmine seem to be most clearly correlated with its central actions in reducing brain $\mathrm{AChE}$ activity and increasing $\mathrm{ACh}$ levels. These findings confirm and extend our earlier studies which indicate an important role of the cholinergic system in behavior.

One might have expected that methylatropine would antagonize some of the effects of neostigmine on behavior. The data indicate it did not. Hence, it appears that the behavioral effects of neostigmine are primarily $n$ cholinergic. The peripheral $m$-cholinergic effects of neostigmine would be cxpected to be blocked by such a pretreatment. Another unexpected finding was that with methylatropine pretreatment physostigmine caused from 22 to $59 \%$ inhibition of brain AChE (see Table 1) depend- 


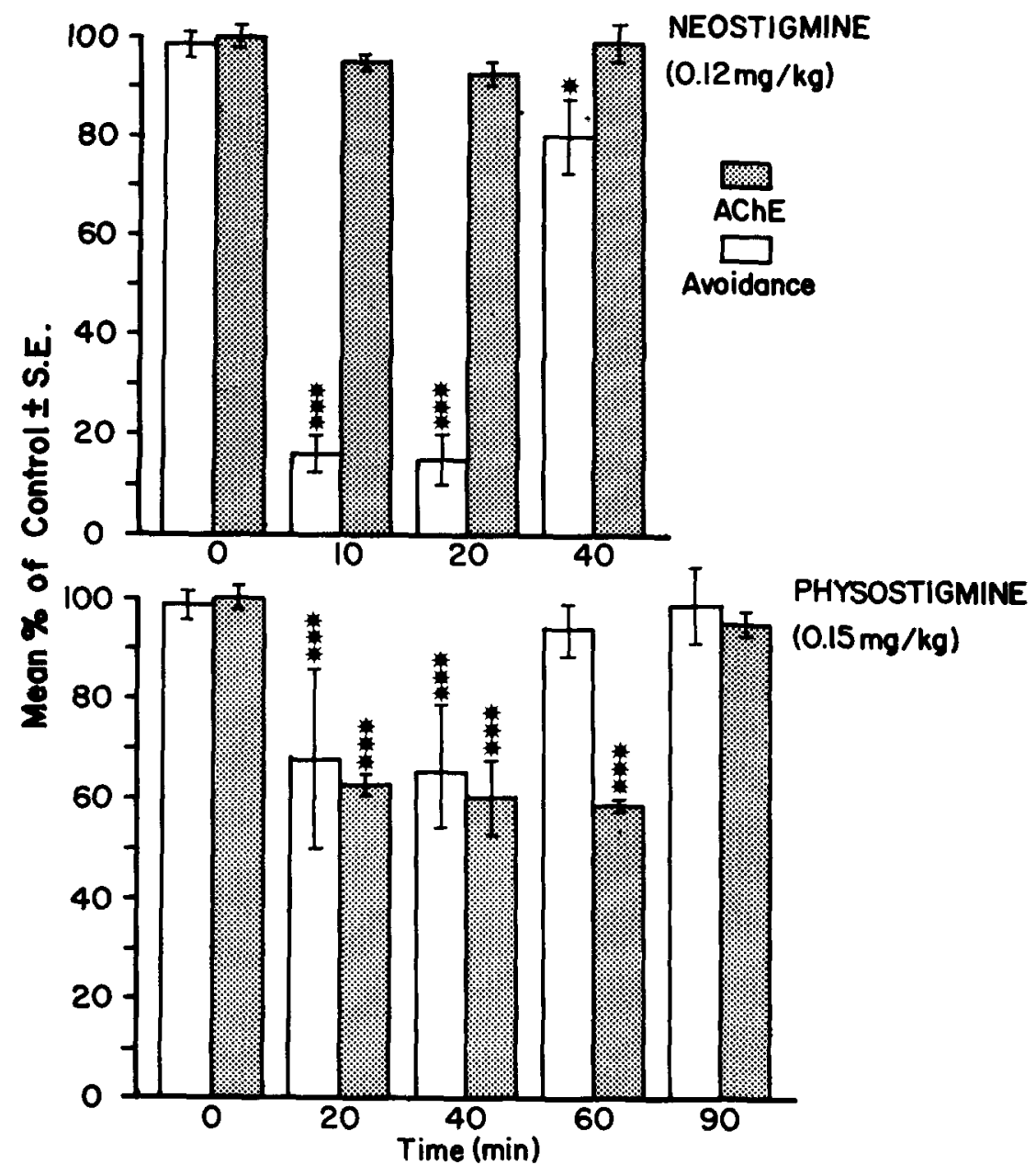

FIG. 1. Effects of an equimolar dose of neostigmine and physostigmine on brain acetylcholinesterase activity and the performance of pole-jumping avoidance. All animals were pretreated with atropine methyl nitrate $(2.1 \mathrm{mg} / \mathrm{kg}) 30 \mathrm{~min}$ prior to a dose of the cholinesterase inhibitor. The dose of neostigmine was 0.12 and physostigmine $0.15 \mathrm{mg} / \mathrm{kg}$, s.c. The behavioral data are given as the mean \pm S.E. in groups of 6-12 animals. Chemical estimations were conducted in 3-6 animals at each time interval. Control AChE activity was $859 \pm 40 \mu \mathrm{M} / \mathrm{g} / \mathrm{hr}$. In the physostigmine treated animals, brain AChE levels were significantly lower than control levels at 20,40 and $60 \mathrm{~min}$ following each dose. Group comparison tests were run comparing each to the control. $* p<0.01, * * * p<0.001$.

ing upon the dose given. Domino and Olds [3] previously reported that relatively small amounts of physostigmine alone $(0.1 \mathrm{mg} / \mathrm{kg}$, s.c.) produced a $56 \%$ decrease in brain AChE. It may be that enough methylatropine was present in the brain homogenates in vitro to partially protect $\mathrm{AChE}$ from inhibition by the physostigmine. The point needs to be examined further for this discrepancy is disturbing.

The behavioral consequences of an increase in brain $\mathrm{ACh}$ are primarily a reduction in responding (no-go behavior) in spite of being awake [2]. The present findings support the data of Grossman [5] which also suggest that the central cholinergic system is inhibitory to most behaviors. 


\section{REFERENCES}

1. Bennett, E. L., M. C. Diamond, D. Krech and M. R. Rosenzweig. Chemical and anatomical plasticity of brain. Science 146: 610-619, 1964.

2. Domino, E. F. Role of the central cholinergic system in wakefulness, fast wave sleep and "No-Go" behavior. In: The Present Status of Psychotropic Drugs, edited by A. Cerletti and F. J. Bove. Amsterdam: Excerpta Medica Foundation, 1969, pp. $273-277$.

3. Domino, E. F. and M. E. Olds. Cholinergic inhibition of selfstimulation behavior. J. Pharmac. exp. Ther. 164: 202-211, 1968.

4. Goldberg, M. E., H. E. Johnson and J. B. Knaak. Inhibition of discrete avoidance behavior by three anticholinesterase agents. Psychopharmacologia 7: 72-76, 1965.

5. Grossman, S. P. Cholinergic synapses in the limbic system and behavioral inhibition. Res. Publ. Assoc. Res. Nerv. Ment. Dis. 50: $315-325,1972$.
6. Michelson, M. J. Pharmacological evidence of the role of acetylcholine in the higher nervous activity of man and animals. Activ. Nerv. Sup. (Praha) 3: 140-147, 1961

7. Pfeiffer, C. C. and E. H. Jenny. Inhibition of conditioned response and the counteraction of schizophrenia by muscarinic stimulation of the brain. Ann. N. Y. Acad. Sci 66: 753-764, 1957.

8. Rosecrans, J. A., A. T. Dren and E. F. Domino. Effects of physostigmine on rat brain acetylcholine, acetylcholinesterase and conditioned pole jumping. Neuropharmac. 7: 127-134, 1968.

9. Vaillant, G. E. Antagonism between physostigmine and atropine on the behavior of the pigeon. Arch, exp. Path. Pharmak. 248: 406-416, 1964.

10. Vaillant, G. E. A comparison of antagonisms of physo stigmine-induced suppression of behavior. J. Pharmacol. exp. Ther. 157: 636-648, 1967. 